\title{
Key challenges facing metropolitan cities or municipalities in managing competitive advantage through technology and innovation
}

\begin{tabular}{|c|c|}
\hline \multicolumn{2}{|c|}{ 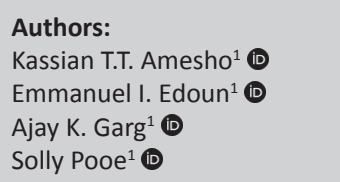 } \\
\hline \multicolumn{2}{|c|}{$\begin{array}{l}\text { Affiliations: } \\
{ }^{1} \text { Tshwane School for } \\
\text { Business and Society, Faculty } \\
\text { of Management of Sciences, } \\
\text { Tshwane University of } \\
\text { Technology, Pretoria, } \\
\text { South Africa }\end{array}$} \\
\hline \multicolumn{2}{|c|}{$\begin{array}{l}\text { Corresponding author: } \\
\text { Kassian Amesho, } \\
\text { kassian.amesho@gmail.com }\end{array}$} \\
\hline \multicolumn{2}{|c|}{$\begin{array}{l}\text { Dates: } \\
\text { Received: } 08 \text { Nov. } 2020 \\
\text { Accepted: } 23 \text { Apr. } 2021 \\
\text { Published: } 23 \text { June } 2021\end{array}$} \\
\hline \multicolumn{2}{|c|}{$\begin{array}{l}\text { How to cite this article: } \\
\text { Amesho, K.T.T., Edoun, E.I., } \\
\text { Garg, A.K. \& Pooe, S., 2021, } \\
\text { 'Key challenges facing } \\
\text { metropolitan cities or } \\
\text { municipalities in managing } \\
\text { competitive advantage } \\
\text { through technology and } \\
\text { innovation', Africa's Public } \\
\text { Service Delivery and } \\
\text { Performance Review } \\
\text { 9(1), a507. https://doi. } \\
\text { org/10.4102/apsdpr.v9i1.507 }\end{array}$} \\
\hline \multicolumn{2}{|c|}{$\begin{array}{l}\text { Copyright: } \\
\text { ( 2021. The Authors. } \\
\text { Licensee: AOSIS. This w } \\
\text { is licensed under the } \\
\text { Creative Commons } \\
\text { Attribution License. }\end{array}$} \\
\hline \multicolumn{2}{|l|}{ Read online: } \\
\hline 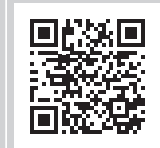 & $\begin{array}{l}\text { Scan this QR } \\
\text { code with your } \\
\text { smart phone or } \\
\text { mobile device } \\
\text { to read online. }\end{array}$ \\
\hline
\end{tabular}

Background: Technology and innovation have become a worldwide feature of business. Virtually, no organisation can survive without technology and innovation. When it comes to developing technology and innovation strategies, managers are often left alone to decide which technology and innovation types to pursue.

Aim: This article investigates the various key challenges faced by metropolitan cities or municipalities in managing competitive advantage through technology and innovation in Kaohsiung Government City, Taiwan.

Setting: The study focused on key challenges faced by metropolitan cities or municipalities in managing competitive advantage through technology and innovation at Kaohsiung City Government in Taiwan.

Methods: The methodology used in this study is mainly the secondary data analysis. A complete and thoroughly secondary data analysis process has been utilised as a research design and approach to complete this research work. This study collected secondary data through comprehensive analysis about various aspects such as document analysis or desktop study, technical reports, scholarly journals, government documents, research institutions.

Results: The result shows that there are various key challenges including research and development and innovation, information security or contingency planning, rapidly advancing technologies, ageing technology and under-investment and the change in residents' expectations.

Conclusion: This article has identified various challenges affecting businesses or organisations, particularly City Governments in competitive advantage through managing technology and innovation. This include inter alias: manpower training and recruiting, organisational transformation, rapidly advancing technologies, ageing technology and underinvestment, the change in residents' expectations.

Keywords: metropolitan cities; municipalities; technological innovation capabilities; competitive advantage; Taiwan; key challenges.

\section{Introduction}

The concept of competitive advantage has changed over time as a result of the technological innovations and modernisation. Competition in the commercial world is inevitable, for that purpose each effort is essential to dependably recognise, comprehend what is going on in the marketplace, what client needs and comprehend the adjustments in the business condition in order to compete with others. Consequently, an endeavour to comprehend what and how to deal with an assortment of assets claimed to win the opposition and produce a competitive advantage should be dependably made. Readiness of new items, even with rivalry from competitors, is one approach to overcome rivalry by using product innovation. Innovation implies distinguishing customers to discover and fulfill client requirements by giving new items or service, making innovation keeping in mind the end goal of obtaining a key spot in the market and overcoming battles from contenders with the principal goal of taking care of the market requirement. Subsequently, it tends to be utilised as a competitive advantage for a business. In this way, organisations are obliged to give new musings, thoughts and inventive items (Kuncoro \& Suriani 2017). 
This progress towards becoming a worth-making business can be consistently utilised by organisations in a type of sustainable competitive advantage (SCA) to meet clients' requests and protests of item quality, client needs, acquirement of new markets and the presence of nonstop product innovation. Besides product innovation strategy, area dynamics may influence the competitive advantage. The vicinity to the market is additionally an imperative interesting point in picking an area. Driving business sector rivalry could inspire organisations dealing in rabbit meat to seek innovation so as to accomplish a SCA. Sustainable competitive advantage is the special arrangement made by the organisation for its clients, perpetually. Sustainable competitive advantage can be understood as the organisation's ability to provide items based on buyers' requests and complaints related to item quality, client needs, acquirement of new markets and product innovation (Kuncoro \& Suriani 2017).

Organisational performance and knowledge optimistically impact a business's innovation (Jiménez-Jiménez \& SanzValle 2011). Having a superior capability for innovation would help an organisation in the innovation-related competition against rivals, thus enhancing organisational performance. An organisation that supports inventive products, eminence procedures or services can profit by new innovation (Leal-Rodríguez et al. 2014). Innovation is a fundamental aspect in technology invention and in strengthening an organisation's competitive advantage, which in turn enhances its inclusive performance.

Innovation empowers organisations to shield themselves from profoundly indeterminate, precarious situations, along these lines making them more fit to look for new chances and effectively abusing existing ones (Kim 2017; Matzler et al. 2013; Svirina, Zabbarova \& Oganisjana 2016). A group's absorptive limit empowers an organisation to transform information into new item quality management, services or procedures to encourage innovation (Cepeda Carrión, Cegarra-Navarro \& Leal-Millán 2012). To create product quality organisations ought to imbibe innovation into their practices, a procedure that requires numerous capabilities and aptitudes (Zahra, Abdelgawad \& Tsang 2011).

The management of technology and innovation (MTI) is a vital issue that all organisations face today. The influx of progress in the business setting incorporates new technologies and innovations that influence industries and organisations or firms to discover better methods to compete and survive. Similarly, as the development of new products is rising exponentially, better approaches for getting things done (new procedures) are being developed to enable firms to be more proficient and powerful. In order to progress, business must discover approaches to managing technology and innovation. These progressions incorporate better approaches to create and implement strategic objectives. These application issues incorporate better approaches to impart the required data, sort out assignments and manage individuals. These methods for progress have resulted in an increasing number of inventers moving past technology and innovation worries into management. Equally, they have likewise pushed directors who never figured they would need to comprehend the complexities of working with technology and innovation to look for learning about such issues. This content is the first to perceive that MTI is not entirely a specialised concern or a business concern. Or maybe, MTI is a space that needs a coordinated approach for students and directors (Margaret \& Garry 2011).

Confronted with a spate of unpredictable competitions threatening business survival, local government authorities or metropolitan cities and municipalities suffer indescribable strain to capture this issue by concocting plans of action that in any event guarantee ensured excellent MTI for sustainable competition, in the wake of overcoming financial difficulties. Intrinsically, the objective of this study is to critically evaluate the significant impact of managing technology and innovation for SCA in the context of metropolitan cities, and also to identify the key challenges faced by metropolitan cities or municipalities in managing technology and innovation for gaining competitive advantage. Therefore, the impact on business survival in an economy defaced with extraordinary and unescapable competition in the business world, which is debilitating the eventual fate of business survival.

Innovation is irreplaceable in modern-day organisations. An organisation's technological invention and its capacity to recognise, distribute and use information specifically influence its competitive advantage (Alavi \& Leidner 2001). Organisations are frequently thought to be a critical buildingblock in the modern knowledge-based economy (Cummings 2004). In that capacity, organisations have made critical investments in actualising an information management ability that is particularly intended to help the sharing of information management capacity amongst individuals in an organisation. Information management ability, with respect to organisational performance could conceivably impart a competitive advantage to organisations. For an organisation to accomplish a competitive advantage, all functions must be interconnected. The working capacity includes an incentive by utilising an organisation's resources efficiently and by creating merchandise and ventures that fulfill the necessities and prerequisites of clients (Singh 2008). This study would provide valuable data in a number of areas such as transparency, accountability, collaboration, e-government, smart cities and Information and Communication Technology (ICT) infrastructure in municipalities or city governments and civic engagement with technology from service providers (Greenberg 2015; Goldsmith \& Crawford 2014; Przeybilovicz et al. 2017; UN 2016). This would help to identify the key challenges faced by metropolitan cities or municipalities whilst managing competitive advantage through technology and innovation. Furthermore, the data obtained from this study would help to make recommendations on how to manage competitive advantage through technology and innovation systems especially for metropolitan cities and municipalities. 
Confronted with a spate of unpredictable competitions threatening business survival, local government authorities or metropolitan cities and municipalities alike, suffer immense strain. Therefore, they have to resolve this issue by concocting plans of actions that in any event guarantee ensured excellent MTI for sustainable competition. This is prompted by the need of the hour for winning financial difficulties. Intrinsically, the objective of this study is to critically evaluate the significant impact of managing technology and innovation for SCA in the metropolitan cities' context and to identify the key challenges facing metropolitan cities or municipalities in managing technology and innovation for competitive advantage. Thus, the impact of technology and innovation on business survival in an economy defaced with extraordinary and inescapable competition in the business world, which is debilitating the eventual fate of business survival.

This article studies the key challenges faced by metropolitan cities or municipalities in managing competitive advantage through technology and innovation. Strategies for managing SCA through technology and innovation is talked about and assessed both subjectively and quantitatively. The inquiry gives more bits of knowledge in the conceivable outcomes of identifying the best strategies for managing SCA through technology and innovation in the local government authorities or metropolitan cities' and municipalities' context. The possibilities for identifying the best strategies for managing SCA through technology and innovation in the local government authorities or metropolitan cities' and municipalities context are noticeably restricted by both external and internal conditions.

\section{Literature review}

\section{Managing technology and innovation: An overview}

Globalisation has led to various changes in contemporary business practices. Recently, technological status has been altered as a result of continuous changes in the global markets. The increasing need and importance of technological business operations has prompted the interest for a fundamental thought of technology and innovation. Hence several concepts have been developed, for instance the Integrated Technology and Innovation Management concepts that stem from (Bleicher 1991) the integrated management theory (Tschirky 1998). Literature reveals (Cavalcante 2013; Cozzarin, Kim \& Koo 2017) that a particular focus on the MTI reflects, on the one side, the escalating predominance of technology and innovation in deciding an organisation's genuine business feasibility. On the other end, it makes up for the extremely disparaged effect of technological change on an organisation's competitiveness as portrayed in present-day management literature (Tschirky 1998).

The innovative smart city government solutions arising from digital technologies, for instance, smart energy, smart food security and smart environments, must be applied appropriately to attain the sustainable goal of smart city governments with low-carbon, ecofriendly, green-energy, recycling and liveable environments (Wu et al. 2018). Technology management itself acclimatises to these new environmental settings with a change from managing technology towards managing technology-based organisations, both new and the already established ones. This implies the representation of technology management being the missing connection between science and technology (S\&T) and overall management. Notwithstanding a missing link and along these lines an action 'outside' overall management, technology and innovation management should be considered as an incorporated part 'inside' of general management (Tschirky 2004). This move, which essentially happens within large, multinational companies merges the extent of the 'Integrated Technology and Innovation Management' in substantial and new technological innovation-based firms, in light of the fact that in new technology-based firms (NTBF), S\&T and management are naturally firmly connected (Cavalcante 2013).

Przeybilovicz et al. (2017) investigated the use of information and communication technology to characterise municipalities: who they are and what they need to develop e-government and smart city initiatives? Their study examines the infrastructure characteristics and application of information and communication technologies of Brazilian municipalities contemplating on the prospect of developing e-government and smart cities actions. They employed a quantitative study technique of cluster analysis, using data from the research 'Munic 2014', which identified four different clusters, namely the Technology less, the Concerned-on citizen, the Concerned-on legislation and the ICT Supported. These four different clusters proposed various options of action in ICT. They found out that there are limitations in the application of ICTs by municipalities or city governments; however, there have been developments with regard to the scenarios of 2009 and 2012 (Przeybilovicz, Da Silva \& Cunha 2015). The inadequate utilisation of ICT by most municipalities may result in investments in inefficient e-government efforts and smart cities (Attour \& Chaupain-Guillot 2020; Visvizi et al. 2018; Zhao, Collier \& Deng 2014).

The application of ICT has the potential to transform the economic prospective of the constituency and promote greater competitiveness, propelling towards new business prospects and innovation, whilst prompting the economic capability of a municipality or city government and its ability to transform into a smart city (Attour \& Chaupain-Guillot 2020; Hashem et al. 2016). Determinations should be towards the application of ICT, aimed at transforming life and work in a constituency in a significant way. It is, therefore, imperative for poorer municipalities to obtain financial support and/or resources for financing basic ICT infrastructure from other sectors of government (Attour \& Chaupain-Guillot 2020; Visvizi et al. 2018). 
Elsewhere, El-Kholei and Al Jayyousi (2019) elucidated on the linkages between technology-driven innovation, innovative capabilities, activities and their influence on innovation performance in Dubai Municipality. They adopted the methodology of qualitative research using several sources of data, comprising reports, academic research papers, etc. Their study revealed that leadership, culture and infrastructure are critical determining factors for an innovative municipality. They argued that in order to improve innovation performance and sustainable innovation in cities, city governments must invest in digital transformation, smart infrastructure and e-governance. Shearmur and Poirier (2015) explored conceptually and empirically, the extent to which municipal innovation resembles innovation in small and medium-sized enterprises (SMEs). Their investigation focused on exploring municipal innovation, emphasising on technological and original innovation in municipalities.

De Vries, Bekkers and Tummers (2016) observed that much of the city government's infrastructure investments are all directed towards sustainable development, improving the quality of life of city inhabitants and strengthening the city government's competitiveness. As the world is becoming progressively more digitised. cities are becoming digital models of the cyber ecospheres in which people dwell (Yu \& Lee 2017) and the development and application of ICT is playing a significant role in this transformation.

Owing to the implementation of innovative ICT, Taiwan continues to support several initiatives associated with smart technology and strategies to build a modernised smart city with the following features: low-carbon, green and harmonious with a sustainable development (Wu et al. 2018). The Industrial Economics and Knowledge Center (IEK) demonstrated that the smart cities development must progress from the standpoint of resolving challenges to fulfill market requirements and with the prospect to construct value and nurture industry. Su et al. (2017) articulated that subsequent to a worldwide economic downturn and an upsurge of domestic economy, the development of smart cities has progressively changed globally to a great extent and encouraged public participation by using a bottom-up strategy and a state-of-the-art economic model of digital economic value added (EVA). The beneficial effects of smart city development can be considered in four proportions: ecological sustainability, social sustainability, economic sustainability and governance (Su et al. 2017).

The perspectives of citizens towards the environment and organisations enthusiastically partaking in the development of smart city are of huge significance (Yu \& Lee 2017). Kaohsiung City Government embraces the management and governance framework that aimed at promoting green transportation information services, whilst improving public service efficiency, creating a new mobile objective for the city and establishing a favourable environment that has low-carbon emission and sustainable (National Development Council 2015).

\section{An understanding of technological innovation}

The main prerequisite for innovation is that the product, process, promoting technique or organisational strategy must be new (or essentially enhanced) to the organisation. This incorporates products, procedures and techniques that organisations are the first to develop and those that have been received from different organisations or companies as observed in literature, the diverse brands of innovation include product innovation, process innovation, marketing innovation, organisational innovation and paradigm innovation amongst others (Gibbons 1994). All these forms of innovation either refer to the creation of something completely new or the improvement in the products of processes. In a nutshell, innovation is defined by Morck and Yeung (2001) as the implementation of new ideas in the business process or the first attempt to carry out an idea into practice.

Innovation is becoming progressively more influential in boosting competitiveness in organisational operations and service management (Rampersad, Plewa \& Troshani 2012). Defined as 'the process of turning opportunity into new ideas and of putting these into widely used practice' (Lin \& Ho 2007), innovation is essential to help firms to persist under adverse global financial circumstances and subsequently playing a key role in creating sustainable competitiveness (Wu \& Lin 2009). Modern firms are knowledge-based organisations and their performance is influenced by both creativity and innovation (Martins \& Terblanche 2003). The concepts of creativity and innovation are inseparably interconnected but also theoretically dissimilar (Dino 2015).

'Creativity' and 'innovation' have been used synonymously in various literatures (Lee, Hallak \& Sardeshmukh 2019; Martins \& Terblanche 2003), yet there are distinctions to be taken into account in their applications. 'Creativity' concentrates on the creation of new and innovative ideas, whilst 'innovation' is the application of creativity (i.e. new and innovative ideas) in a particular situation with the consequence of generating worth (Dino 2015; Lee et al. 2019). Innovation from an organisational perspective is defined as:

[T] ] intentional introduction and application within a role, group, or organisation of ideas, processes, products, or procedures, new to the relevant unit of adoption, designed to significantly benefit the individual, the group, the organisation, or wider society. (West \& Farr 1990 cited in Martins \& Terblanche 2003:3)

The concept of technological innovation stems from the scholarship of innovation studies and it explains the processes of technological change and its implications thereof. Initially, Freeman (1995) maintained that this concept was introduced under the scholarship of the Innovation System Approach (ISA) that maintains that the broad technological innovations are rooted in societal structures where the firms are based as opposed to niche firms or research institutions as the foundations of technological innovation. Freeman (1995) also noted through societal studies that society has significantly 
been influential in bringing about technological change, which positively impacts economic development and change. Visvizi et al. (2018) sought to tie technology-driven innovation on the one hand and both social and economic sustainability on the other. They contended that technology enablers lead to a smart city strategy, thus raising social wellbeing. The technology-innovation interface is clear in private sector companies. It is not the case in public sector institutions. Creativity in organisations can equally help to develop from actors outside the organisation. These outside actors can be customers, clients, professional bodies, crossboundary networks, etc. (Anderson, Potocnik \& Zhou 2014). Furthermore, creative ideas can be produced from observing and emulating competitors, collecting customer opinions or feedback, holding consultations with suppliers or gaining access to University and Government research (Lee et al. 2019). For the purpose of establishing what ideas are creative, one needs to know what ideas are not considered creative (Simonton 2016). Creative ideas are a 'multiplicative product of originality, utility and surprise', whilst uncreative ideas are repetitive or usual, casual responses (Simonton 2016).

However, although this is seen as an important aspect for development, scholars such as Suurs (2009) note that it is equally important to consider that knowledge that flows through research and development is not really sufficient to induce technological change and the development of an economy, hence it is also important to consider niche research areas as stimulators for innovation. Overall, technological innovation, when focused in terms of system dynamics, is broadly seen as a vital element in the competitive status of an organisation and is seen in the organisational structures, processes, goods and services in an organisation (Yam et al. 2004).

In light of these scholars, technological innovation is said to be related to the management of the components of the organisation through knowledge management, technics and skills improvement with the whole intention of increasing the competitiveness of the business entity (Yam et al. 2004).

Considering these contemporary explanations on technological innovations and its implications on competitiveness, early scholarly articles also raise similar arguments. In fact, current scholarly articles on technological innovation build upon early works on this subject $(\mathrm{Na}$, Kang \& Kim 2018). Schumpeter and Redvers (1934) talked about innovation as involving new products and services, new methods of producing and distributing goods, new sources of customers and suppliers, exploration of new markets and new organisation of businesses.

\section{Factors affecting technological innovation}

Considering the preceding discussion and the linkage of technology and innovation, scholars such as Şener and Sarıdoğan (2011) maintain that for technological innovation, there is need for intensive research and development and the intervention of various players in the society. Similarly,
(Crespi 2004) also revealed that technological innovation is a complex aspect and is multifaceted to the extent that there are many factors that influence it where research and development play a key role. Whilst research and development are considered as an important aspect, Crespi (2004) further stated that it is equally important to consider that there is a need for the creation of a culture and environment that promotes technological innovation and related innovative activities on a local and national scale. Importantly, for there to be an effective technological innovation, there is need for the linkage between various players in the community such as business organisations, individuals, universities, state-owned research including the efforts of the civil society.

Figure 1 shows the linkages between different players of the community and how they influence the innovation process. The figure shows that the individuals, non-governmental organisations, state supported research, universities and firms all influence the innovation process. As previously observed, there is need for intensive research and development to ensure that there is continuous innovation in the organisation. On this note, the individuals are the key players in the research and development because without people and the related human capital, there will be no research or any technological and innovation aspects.

However, the humans on their own cannot trigger research and the development of various innovations. They need to be linked with the research centres, organisations, universities, the government an $\mathrm{d}$ other private organisations. The universities in this case are centres of higher education and they provide useful information, expertise, different methodologies and other research paradigms to come up with effective innovative ideas.

Similarly, the state-supported research institutions provide important knowledge and expertise at a subsidised cost. This is because the role of the state is to provide merit and community goods. Thus, in terms of technological innovation as an important aspect for economic development, the state can provide relevant information that will lead to

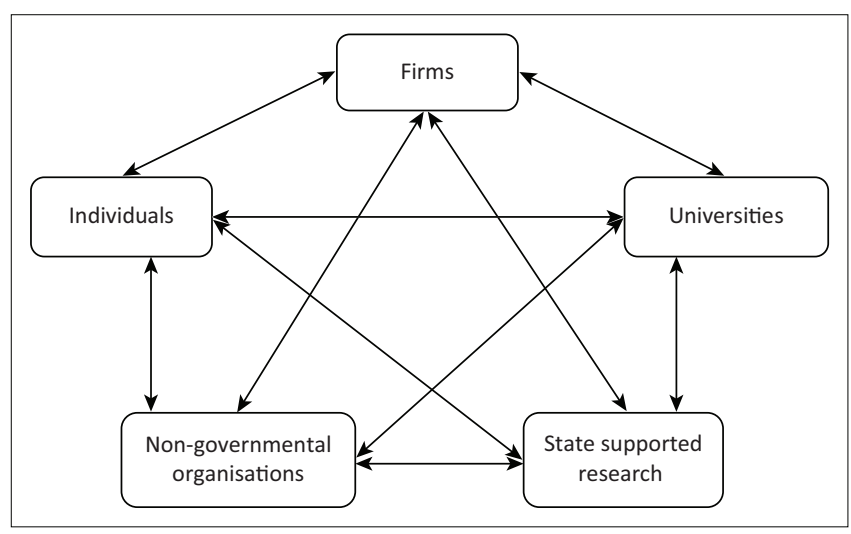

Source: Adopted from Schilling, M.A., 2010, Strategic management of technological innovation, Tata McGraw-Hill Education, New York, NY.

FIGURE 1: Sources of technological innovation as a system at a local scale. 
the creation of new ideas that are beneficial for the nation and their intervention is at a low or no cost at all.

The involvement of the non-governmental organisation in the technological innovation process is also important in the sense that they link the individuals with important private players that play significant roles on the research in question. On this note, the linkage between the individual researchers or the civil society and the relevant people enables the creation of innovative ideas that can be adopted by the firms for their advantages. The firms in this regard refer to business organisations that are affected by the need for and the drive to introduce competitive and technologically innovative ideas.

\section{Porter's Five Forces Model and competitive advantage}

Given that competition is an on-going concept in the organisation and it is therefore important that organisation such as city governments or municipalities need to stay abreast of their competitors in the market. In this context, the Porter's Five Forces Model would help the city government or municipalities' management to understand competition dynamics and how to overcome challenges faced through technological innovation. Porter's Five Forces Model is a marketing aid that helps businesses (including city governments or municipalities) to appreciate the structure of their operative industry by enabling it to understand the threats and opportunities they may face outside their microenvironment (Porter 2008). In relation to this research investigation, this model is quite applicable in a sense that it would be useful to determine the key challenges facing metropolitan cities or municipalities in managing competitive advantage through technology and innovation. To this effect, the Porter's Five Forces Model has five forces that shape competition within an industry and which have an implication on the performance of an organisation - measured through its profitability, attractiveness, market share, success and/or high production amongst other dimensions (Porter 2008). This is useful both in understanding the eminence of an organisation's existing competitive standpoint and the significance of a position that an organisation may hope to move into. Figure 2 shows Porter's Five Forces Model.

Figure 2 shows five forces that are found in the market environment of an entity and have an implication on the marketing and competitiveness of an organisation. These forces are the risk of entry by potential competitors, the bargaining power of buyers, the bargaining power of suppliers, the threat of substitutes and the resulting intensification of competitiveness amongst prevailing competitors (Porter 1979, 1996, 2008). In terms of risk of entry by prospective competitors, emphasis is placed on potential competitors who have not yet explored the market and exert competitive pressure on the organisation in question. These organisations, however, have the capability to explore the market and join in the competitive race of being the best entities amongst others. Whilst the firm's capacity may enable it to explore new markets, thus posing the actual competitive forces - it is essential to note that entry into markets is determined by the barriers to entry. The risk of entry worries potential contenders who are not yet contending in your industry but rather have the ability to do as such on the off chance that they pick. These competitors may only become real competition if they determine and overcome the barriers to entry into the new markets, which are usually explained by the costs involved, for example, how costly an investment in question is and how much profits can be achieved if an organisation decides to join in the race (Porter 2008). The issue of entry of potential competitors is even more complex in the contemporary business environment where technological innovation is at its best because new production processes are introduced, which further increases competition amongst different firms.

\section{Technological innovation and competitive advantage}

Whilst the discussion on technological innovation is continuing, there are various links that have been found on how technology can lead to competitive advantage for an organisation. According to Porter and Millar (1985), the main aim of the adoption and use of technological devices by businesses is to save costs. On this note, Porter and Millar (1985) observed that the use of technology has an implication on saving money, effort and time and importantly, achieving a competitive advantage more than their rivals. This can be achieved in several ways that

\begin{tabular}{|c|c|}
\hline $\begin{array}{l}\text { Rivalry amongst } \\
\text { existing competitors: } \\
\text { - Number of competitors } \\
\text { - Diversity of competitors } \\
\text { - Industry concentration } \\
\text { - Industry growth } \\
\text { - Quality differences } \\
\text { - Brand loyalty } \\
\text { - Barriers to exit } \\
\text { - Switching costs }\end{array}$ & $\begin{array}{l}\text { Threat of new entrants: } \\
\text { - Barriers to entry } \\
\text { - Economies of scale } \\
\text { - Brand loyalty } \\
\text { - Capital requirements } \\
\text { - Cumulative experience } \\
\text { - Government policies } \\
\text { - Access to distribution } \\
\text { channels } \\
\text { - Switching costs }\end{array}$ \\
\hline $\begin{array}{l}\text { Bargaining } \\
\text { power of } \\
\text { suppliers }\end{array}$ & $\begin{array}{l}\text { Bargaining power } \\
\text { of buyers }\end{array}$ \\
\hline $\begin{array}{l}\text { Bargaining power of suppliers: } \\
\text { - Number and size of suppliers } \\
\text { - Uniqueness of each supplier's } \\
\text { product } \\
\text { - Focal company's ability to } \\
\text { substitute }\end{array}$ & $\begin{array}{l}\text { Bargaining power of } \\
\text { buyers: } \\
\text { - Number of customers } \\
\text { - Size of each customer } \\
\text { order } \\
\text { - Differences between } \\
\text { competitors }\end{array}$ \\
\hline $\begin{array}{l}\text { Threat of substitute products: } \\
\text { - Number of substitute } \\
\text { products available } \\
\text { - Buyer propensity to substitute } \\
\text { - Relative price performance } \\
\text { of substitute } \\
\text { - Perceived level of product } \\
\text { differentiation } \\
\text { - Switching costs }\end{array}$ & $\begin{array}{l}\text { - Price sensitivity } \\
\text { - Buyer's ability to } \\
\text { substitute } \\
\text { - Buyer's information } \\
\text { availability } \\
\text { - Switching costs }\end{array}$ \\
\hline
\end{tabular}

Source: Porter 1979, 1996, 2008

Note: Please see the full reference list of the article, Amesho, K.T.T., Edoun, E.I., Garg, A.K. \& Pooe, S., 2021, 'Key challenges facing metropolitan cities or municipalities in managing competitive advantage through technology and innovation', Africa's Public Service Delivery and Performance Review 9(1), a507. https://doi.org/10.4102/apsdpr.v9i1.507, for more information. FIGURE 2: Porter's Five Forces Model. 
include the selection of only the best systems, relying on support that grows as the organisation develops, staying true to the organisation's core business, cutting costs on recruitment and the use of experts at their call (Porter \& Millar 1985).

\section{Selecting the best possible systems}

One of the essentials of technological innovation in the organisation as identified by Porter (2008) is that it gives them the propensity to select the best possible systems from the pool of solutions to choose from. This is especially important in the present-day tenders and procurement processes where the organisation has to carefully pick the right suppliers to deal with that added value to the entity and their customers. The use of technological innovation allows them to easily access alternative suppliers' recommendations, references and certifications and decide on the best possible supplier amongst all of them (Uyarra et al. 2014). Similarly, technological innovation allows business enterprises to also request demos and trials to get a first-hand experience of a digital tool's design and usability. In a nutshell, Porter (2008) stated that with the available technologies, an organisation has all the available resources at its disposal to make a well-informed decision and conclude the deal. This is made possible with the available software that allows them to compile cost-benefit analysis on any available proposal and make a decision that best suits their purpose (Porter 2008).

\section{Relying on support that grows as the organisation develops}

In addition to the issue discussed here, Porter (1996) also observed that the use of technological innovation is essential for competitive advantage in the sense that it allows organisations to grow together with changes in technology. In light of this, organisations are able to design their advanced tools to oblige organisations of various sizes, and also changes in those sizes. This leaves organisations with the flexibility to become uncontrolled without worrying about supporting issues. This is certainly an edge over their rivals that need to control their development as a result of absence of sufficient support (Porter 2008).

\section{Cutting costs on recruitment}

Another challenge that organisations face is that of increased recruitment and selection costs. Literature reveals that the contemporary business practices are characterised by high employee turnover and workers mobility as they seek better working conditions and opportunities for their relevant experience. On this note Porter (2008) is of the view that the available technological innovation allows an organisation to build a strong connection between information technology and human resources department such that the link between these two will enable the organisation to cut costs when recruiting and selecting key employees for the available jobs. The available technologies should be able to screen potential employees to the extent that huge costs associated with inviting wrong candidates for interviews are minimised. If a business is able to save costs in this regard and is able to implement these aspects better than its competitors, it is more likely to gain a competitive advantage in the short- and long-term.

Use of technological innovation for operations - further, the availability of technological innovation is seen as essential for the benefit of the business in its operations. Porter (2008) furthermore stated that technology itself is a fast-growing business aspect and is essential for making the business competitive in a market full of contenders. The use of technological devices adds value to the organisation in the sense that they make it easier for the clients to communicate with the organisation through the available technologically innovative systems. Porter (2008) also mentioned that use of information technology in organisations is often an overlooked resource, but once business enterprises know how to harness it, Information Technology (IT) expertise will be within their reach without the added cost. Studies conducted by McAdam and Keogh 2004 to ascertain the relationship between the performance of firms and their familiarity with innovation and research came to the conclusion that the ability of firms to lean from their innovation is essential for their competitive standings in the market.

They found that technological innovation allows them to be unique, apply efficient business practices, reduce waste and increase their chances of improving in relation to the existing market dynamics. In similar studies conducted, it was found that technological innovation enables a firm to attain competitive advantage as opposed to its contenders in the market.

\section{Research methodology Research method used in this study}

A comprehensive secondary data analysis technique was exploited in this research study. The subjective research technique is utilised to assist answering inquiries concerning the nature of phenomena with the motivation behind depicting and understanding them from the secondary data analysis point of views. Denzin and Lincoln (2008) alluded that 'qualitative research is multi-technique in emphasis, comprising an explanatory real-life way to deal with its topic'. In other words, the qualitative research methodology makes it easy for the analyst to assess things in their natural surroundings while endeavouring to understand or interpret occurrences concerning the consequences on individuals. Furthermore, this research is not restricted in esteem rather it provides a comprehensive investigation of the subject area being considered (Bryman et al. 2018).

\section{Advantages of secondary research}

Whatever kind of research you are directing or carrying out, it is advisable to know about its qualities and confinements. A standout including the best favourable conditions is that compared with essential research, secondary research is 
reasonable and cost-effective (The Oxbridge Exploration Gathering Ltd 2017). Primary research more often than not requires spending a considerable measure of resources in terms of money. For instance, people from the research cluster should be remunerated. You might require recompensing for workplace space and equipment and compensate your associates for involvement. There may be further operating cost expenditures too. These costs do not occur whilst conducting secondary research. Despite the fact that investigators might require acquiring secondary data sets, this is in every case less expensive than if the study were to be steered without any preparation (The Oxbridge Exploration Gathering Ltd 2017; McAdam \& Keogh 2004).

\section{Secondary data analysis process}

Johnston (2012) submitted that technological developments have prompted immense measures of information that has been gathered, ordered and chronicled and that is currently effectively available for research. Although secondary analysis is adaptable and could be used in a few different methods, it is likewise an experimental workout and a deliberate technique with bureaucratic and evaluative advances, similar to gathering and assessing primary data. This study affirms that secondary data analysis is a feasible strategy to use during the time spent on request when a deliberate method is taken after and gives an explanatory research presentation using secondary data analysis in managing technology and innovation study.

\section{Data collection}

This study collected secondary data through comprehensive analysis about various aspects such as workshops, document analysis/review or desktop study, official statistics, technical reports, scholarly journals, literature review articles, trade journals, reference books, government documents, research institutions, universities, libraries, inter alias, in order to obtain relevant secondary data from management information systems (McCaston 2005) on a convenient basis from the Taiwanese Nationwide Document Delivery Service (NDDS), through the Science and Technology Policy Research and Information Center (STPI) under the Ministry of Science and Technology, which is related to the Kaohsiung City Government, Taiwan. The measuring instrument for this study was determined after a thorough literature review had been carried out.

\section{Data analysis}

The comprehensive and detailed secondary data analysis was critically analysed, scrutinised and evaluated for completeness and consistency. The results from secondary data analysis of diverse secondary data sources were organised into themes because of their qualitative nature and then compiled appropriately for analysis. The descriptive analytical methods such as frequency (both absolute frequency and relative percentage) were utilised to define the outcome. The findings were systematised, summarised and presented using tables, pie charts, bar graphs and charts for simplicity and contrast purposes.

\section{Results and conclusion}

\section{The role of organisational structure and duties of city government in supporting technology and innovation}

\section{Organisation system and duties}

The change of hierarchical affairs of Kaohsiung City Government depended on the full-scale vision created in the Kaohsiung region. The city has an all-inclusive deliberation of the social attributes of the province and city organisation, business obligations' disposition, economic and ecological changes and in addition the requirements of adversity deterrence measures, rebuilding of disaster-hit spots and redisposition of basic living circle after restructuring (KCG 2015, 2016). The study has also revealed that when it was guaranteed that the rights and benefits of staff individuals were totally secured, organisational alliance was completed, setting up 23 Bureaus, namely Civil Affairs, Finance, Education, Economic Development, Marine, Agriculture, Tourism, Urban Development, Public Works, Hydraulic Engineering, Social Affairs, Labor, Police, Fire, Public Health, Environmental Protection, Mass Rapid Transit, Cultural Affairs, Transportation, Legal Affairs, Military Service, Land Administration and Information; 4 Offices, namely Secretariat, Accounting and Statistics, Personnel and Civil Service Ethics; and 3 Commissions, namely Research, Development and Evaluation, Indigenous Affairs and Hakka Affairs, having a total of 30 first-level agencies. In addition, there are 35 regional offices, 3 mountain indigenous regional workplaces and 145 subordinating offices, with an overall 213 offices and 357 schools of various levels (comprehensive of open university and kindergartens) (KCG 2015, 2016).

\section{Disposition and number of civil servants in the Kaohsiung City Government}

The study revealed that the staffing of every department or school of the City Government depended on the observation for the genuine business needs and monetary weight. Under the standards of 'adaptability, insightfulness, efficiency', mindful and rational recruitment was made. The study found out that in 2016, there were 37 staff working in the head office of the City Government, 6034 staff working in first-level departments, 14984 staff working at regional offices (excluding mountain indigenous regional offices) and second-level departments and 23613 staff working at schools of various levels, their status in terms of age, their education levels and their civil services examination with a sum of 44631 staff hired (KCG 2016) (see Table 1).

\section{Research and Development in supporting technology and innovation at the Kaohsiung City Government}

Promoting research and development

Outsourcing of research projects: In order to encourage the municipal development and reinforce scholarly and 
TABLE 1: Research projects outsourced by Kaohsiung City Government agencies, 2014.

\begin{tabular}{|c|c|c|c|}
\hline Number & Agency & Research topic & Commissioned organisation \\
\hline 1 & Environmental Protection Bureau & Establishment and Promotion of Biodiversity Data & Ming-Shiang Ecological Census Consultant Co., Ltd. \\
\hline 2 & Environmental Protection Bureau & $\begin{array}{l}\text { A Project on the Investigation of Biodiversity in the Urban Areas of } \\
\text { Kaohsiung City }\end{array}$ & Kaohsiung Wild Bird Society \\
\hline 3 & Bureau of Cultural Affairs & $\begin{array}{l}\text { Outsourced Study on the 'Human Resources of Taiwan's Film and } \\
\text { Television Industries and Its Correlation with the Training of } \\
\text { Professional Personnel for the Film and Television Industries of } \\
\text { Southern Taiwan' }\end{array}$ & National Kaohsiung University of Applied Sciences \\
\hline 4 & Bureau of Cultural Affairs & $\begin{array}{l}\text { 'Outsourced Research Proposal for Writing on the Duck-Seller King } \\
\text { of Neiman, Yi-Kuei Chu' }\end{array}$ & Individual \\
\hline 5 & Bureau of Cultural Affairs & $\begin{array}{l}\text { Investigation and Research into the Architectural History and } \\
\text { Humanistic Context of the Historical Street Blocks of the Third } \\
\text { Category of Plaza Land in the Gushan District of Kaohsiung City }\end{array}$ & National University of Kaohsiung \\
\hline 6 & Bureau of Cultural Affairs & $\begin{array}{l}\text { Preliminary Study on the General Development of Art Galleries in } \\
\text { Kaohsiung }\end{array}$ & Tainan University of Technology \\
\hline 7 & Bureau of Cultural Affairs & $\begin{array}{l}\text { Investigation and Restoration Project of the Kaohsiung Municipal } \\
\text { Historic Site - Original Patriotic Women's Association Site }\end{array}$ & $\begin{array}{l}\text { Department of Architecture, Chung Yuan Christian } \\
\text { University }\end{array}$ \\
\hline 8 & Bureau of Cultural Affairs & $\begin{array}{l}\text { Outsourced Research on the Kaohsiung Museum of History's } 2013 \\
\text { Collection of Ceramic Artifacts }\end{array}$ & $\begin{array}{l}\text { Department of Art History, Tainan National } \\
\text { University of the Arts }\end{array}$ \\
\hline 10 & Bureau of Cultural Affairs & Taiwanese Women's Art Chronicle Book Compilation Project & Kun Shan University \\
\hline 11 & Bureau of Cultural Affairs & $\begin{array}{l}\text { Discovering the Innocent Minds of Children: A Study on the } \\
\text { Assessment and Planning of the Operating Environment for the } \\
\text { Children's Museum of Art }\end{array}$ & National Sun Yat-sen University \\
\hline 12 & Fire Bureau & Disaster Prevention Plan for Kaohsiung City, 2013 & $\begin{array}{l}\text { National Kaohsiung First University of Science and } \\
\text { Technology }\end{array}$ \\
\hline 13 & $\begin{array}{l}\text { Research, Development and } \\
\text { Evaluation Commission }\end{array}$ & $\begin{array}{l}\text { A Study on Employment Trends among Graduates of Colleges and } \\
\text { Universities in Kaohsiung City }\end{array}$ & $\begin{array}{l}101 \text { Technology Management and Consulting Co., } \\
\text { Ltd. }\end{array}$ \\
\hline 14 & Education Bureau & $\begin{array}{l}\text { A Project on the Study of the Establishment of Indicators for } \\
\text { Changing the Status of High-Quality Municipal Junior High Schools } \\
\text { in Kaohsiung City into Comprehensive Junior High Schools }\end{array}$ & National Kaohsiung Normal University \\
\hline 15 & Education Bureau & Trial Experiment of a Digital Pedagogies System (DPS), 2012 & $\begin{array}{l}\text { National Pingtung University of Science and } \\
\text { Technology }\end{array}$ \\
\hline 16 & Education Bureau & $\begin{array}{l}\text { Planning and Study of the Feasibility of Operation Strategies for } \\
\text { Kaohsiung National Stadium (Main Stadium for the World Games) }\end{array}$ & UniVenture Management Consulting Co., Ltd. \\
\hline 17 & Education Bureau & $\begin{array}{l}\text { Research on the Developmental Vision of Kaohsiung City } \\
\text { Community University }\end{array}$ & $\begin{array}{l}\text { National Association for the Promotion of } \\
\text { Community Universities }\end{array}$ \\
\hline 19 & Tourism Bureau & $\begin{array}{l}\text { Research on the Developmental Vision of Kaohsiung City } \\
\text { Community University }\end{array}$ & $\begin{array}{l}\text { National Association for the Promotion of } \\
\text { Community Universities }\end{array}$ \\
\hline 20 & Social Affairs Bureau & $\begin{array}{l}\text { Research on and Investigation into the Living Conditions and Needs } \\
\text { of the Elderly }\end{array}$ & Trendgo Research \\
\hline 21 & Economic Development Bureau & $\begin{array}{l}\text { Outsourced Professional Services for the Feasibility Assessment } \\
\text { and Planning of Future Market Development for the Gaoping } \\
\text { Designated Area in Siaogang District of Kaohsiung City }\end{array}$ & Partnerships Taiwan Consulting Ltd. \\
\hline 22 & Finance Bureau & $\begin{array}{l}\text { A Study on the Promotion of Sourcing and Expenditure Reduction } \\
\text { Measures by the Kaohsiung City Government }\end{array}$ & National Sun Yat-sen University \\
\hline
\end{tabular}

Source: Kaohsiung City Government (KCG), 2016, Overview of Kaohsiung City Administration (2016), Research, Development and Evaluation Commission (RDEC), Kaohsiung City Government, viewed 29 July 2018, from http://rdec.kcg.gov.tw/.

administrative collaborations and participation, schools, colleges, universities, research institutions and groups or associations or entities were commissioned to conduct and complete research projects identified with metropolitan development agenda according to the Guidelines for Outsourcing Research Projects by the Kaohsiung City Government (KCG 2016). The research projects were outsourced in 2014 by the Kaohsiung City Government through its various departments to different organisations and individuals. A record of 22 projects were awarded in 2014 (see Table 1).

Research project evaluation: In order to enhance and support technology and invalidation through research and development (R\&D) at the KCG, 23 research projects worth NT\$85 000 were sponsored in 2015 consistent with the Kaohsiung City Government Outlines for Evaluating, Reviewing and Rewarding Research and Development Projects. Generally, 31 organisations had submitted their proposals for consideration as indicated in Figure 3.
Researchers and specialists were yet again chosen to carry out the initial and secondary reviews, and to this effect, 15 projects got the grants. The granted research result reports were sent to suitable departments for reference and got published on the City Government Research Result Website (http://research.kcg.gov.tw/chinese/index.aspx) for the public to download and utilise them (KCG 2016).

\section{Implementing experimental education and encouraging innovative educational philosophy at Kaohsiung City Government}

\section{Improve information technology infrastructure}

The City Government Education Agency has been advancing the Information Technology Tour Service for Schools in Remote Regions of the Kaohsiung county, financing schools to enhance their data innovation foundations and administrations, whilst consistently keeping up and refreshing hardware and offices of personal computer (PC) 


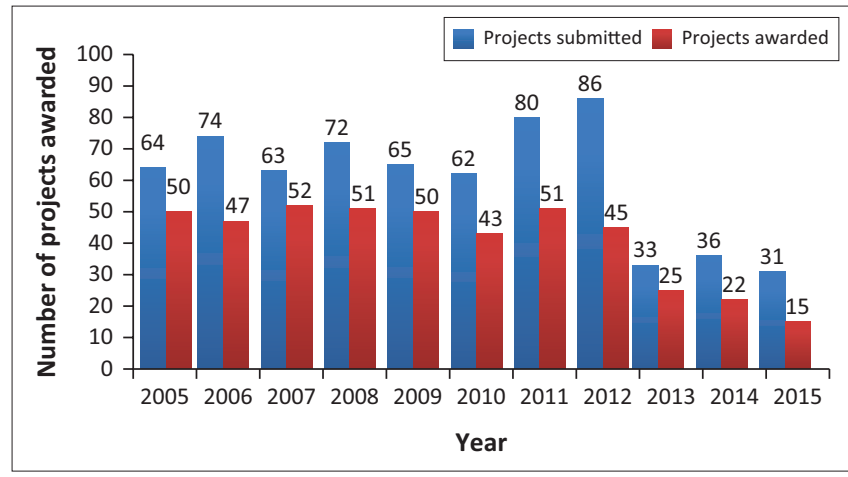

Source: Kaohsiung City Government (KCG), 2016, Overview of Kaohsiung City Administration (2016), Research, Development and Evaluation Commission (RDEC), Kaohsiung City Government, viewed 29 July 2018, from http://rdec.kcg.gov.tw.

FIGURE 3: Kaohsiung City Government research and development results statistics (2005-2015)

rooms in basic and middle schools, setting up Wi-Fi systems on campus and incorporating the Remote Video Conference Systems thereof (KCG 2017).

\section{Factors influencing technology and innovation}

\section{Challenges faced by science and technology development} in Kaohsiung City Government, Taiwan

Research and development and innovation: As technical research and innovation necessitates a sound domain, comprising of a powerful legal and administrative framework, the nation builds up a 'creative driven' development prototypical, the legal and governing framework must react to S\&T development and fast economic and social change through adaptable, appropriate adaptation (Broström \& Karlsson 2017). Specifically, the amendment of the Fundamental Science, Technology and Innovation Act is a pressing need. Moreover, linkage amongst industry, the scholarly world and the research community network must be reinvigorated and needs a focused innovative $R \& D$ and industry-academic joint effort will require support, keeping in mind the end goal to combine research and development capacities with industrial applications and in this manner boost the foundation of new technological companies and drive modern industrial advancement and transformation (Broström \& Karlsson 2017).

Manpower training and recruiting: Predominantly, Human Resources (HR) is a key reason for innovative scientific research in any organisation. Reacting to the rapid advancement of the high-tech economy, Ministry of Science and Technology (Taiwan) (MOST) has effectively drafted interdisciplinary HR development methodologies through recruitment of Science and Technology (S\&T) personnel from 2007 to 2016 (see Table 2) following funding and person-times that are stimulating useful industrial labour training strategies and widening the possibilities of S\&T research labour, which will do much in merging Taiwan's S\&T research establishment (Huang et al. 2010).

Keeping in mind the end goal to recruit first class global scientific research labour, MOST has to rapidly enhance appropriate policy frameworks and provide conducive living and working settings, appropriate for global labour,
TABLE 2: Recruitment of science and technology personnel, 2007-2016.

\begin{tabular}{lcc}
\hline Year & Funding (NT\$1000) & Person-times \\
\hline 2007 & 1121926 & 1242 \\
2008 & 1169286 & 1491 \\
2009 & 1660752 & 2630 \\
2010 & 1978388 & 2755 \\
2011 & 1854242 & 2479 \\
2012 & 1797841 & 2422 \\
2013 & 1867358 & 2393 \\
2014 & 1832694 & 2435 \\
2015 & 1943565 & 2488 \\
2016 & 2121115 & 2660 \\
\hline
\end{tabular}

Source: Ministry of Science and Technology (Taiwan) (MOST), 2018, Statistics Database, viewed 09 February 2018, from https://statistics.most.gov.tw/was2/.

which must be done if the nation is to effectively appeal for global manpower for research and keep up the global standards (Ho 2011; Huang et al. 2010; KCG 2016).

Industrial development and transformation: Numerous new S\&T patterns have developed as of late, including the Internet of Things (IoT), virtual reality (VR), augmented reality $(\mathrm{AR})$ and artificial intelligence $(\mathrm{AI})$. These patterns have fortified new rushes of rivalry amongst worldwide businesses and local industries are thus following a new evolving direction (Huang et al. 2010). Thus, in the current high-tech economy age, benefiting from global S\&T patterns whilst utilising indigenous technological points of interest, outlining a dream for the eventual fate of industry and keeping up adjusted territorial advancement will be the administration's most critical mission whilst helping the change of industry (Huang et al. 2010; KCG 2017).

\section{Other technological factors affecting organisations and their environment}

The following technological factors play a critical role in an organisation as far as managing competitive advantage through technology and innovation is concerned, and inter alias:

- Organisational transformation: It is typically very wearisome especially when a great number of parties are involved as plans will be adjusted. It is recommended to advise workers before time and keep up with the up-to-date enabling reproach when carrying out such improvement (Haned, Mothe \& Nguyen-Thi 2014).

- Business developments: It involves assimilating the contemporary innovation and technology demands, differentiating the business pre-requisites and evaluating the business procedures as per its targets and objectives. These advancements should profit the organisation and the customers (Cozzarin et al. 2017).

- Sustainable competitive advantage: It is defined as taking a look at innovation and technology from a positive viewpoint fairly than an 'important malevolence'. Customary models are shifting and points of interest can be achieved by investing resources into contemporary innovation and technology, but solely achieving innovation and technology for having it is not sufficient, actualising a vital strategic idea is the key to success.

- Costs included: Be that as it may, it's reasonable that a few institutions are unwilling to bear the cost because of 
the frameworks being commonly outdated; however the ones who see this venture as an opportunity to gain the upper hand and have an outstanding created system connected, could profit immensely.

- Competence: Effectiveness, reducing labour costs, economically savvy are general factors as they can streamline, hasten and enhance precision (e.g. agencies can interrelate or check a certain issue or status of a demand/distribution/benefit from several areas in the value chain).

- Information security/Contingency planning: Innovation and technology give a great deal of benefits, hitherto we must equally deliberate over the obligations that accompany it. Organisations should also reflect the growing information rupturing and different cybercrime components and must put resources into persuasive methods for anticipating or battling these issues. Organisations must have these alternate courses of action set up keeping in mind the end goal to ensure their significant resources (Choy \& Park 2016).

For the most part, innovation and technology is useful and organisations should attempt to counter the negatives so as to locate the valuable effect in its implementation.

\section{Factors affecting innovation capacity and capability}

Several public subdivision employees, involving those in the native government, will refer to their inspiration for working in the subdivision as the possibility to have an effect - that is to add to work that rewards society and enhances lives. In any case, and for some reasons, working in the public division can be worrisome due to the fact that the pace of progress is moderate, while the effect is frequently backhanded and endeavour to make change regularly hampered by existing frameworks, procedures or conventions.

The limit and competence of people in these organisations to impact encouraging changes can be improved or restrained by various components. These are not one of a kind for city governments, but rather provide a helpful system to seei how innovative practices are best bolstered inside organisations. The five elements for an innovation culture introduced in Figure 4 informed the preliminary rational for this. Through guided discussions and meetings, a portion of these components rose emphatically, whilst others were viewed as less essential. The perceptions presented here speak to those components that rose most firmly from the other research (Goi 2017).

\section{How technological factors affect the business environment}

Technology and innovation patterns influence organisations and business entities at multiple levels. At the stage when employees are efficient, they end up being productive. Furthermore, when a business is more into interaction with its existing and prospective customers, the more opportunities it has to establish a solid customer trustworthiness base. Evolution of innovation and technology can make this imaginable. Key innovators are always enquiring for development and updates within the innovative and technological environment. Thus, they are not only enhancing their tasks, they will similarly be very much cognisant of the business transformational period. They will extrapolate ground-breaking stratagems to advance their businesses exponentially (Abdulwahed 2017).

\section{Technology transforms operations}

The technological environment of the business has tremendously transformed the manner by which organisations operate. This is the case with the Kaohsiung City Government as the progressions in technology and innovation around data innovation within the City Government have comparatively presumed control over each division of the institution. Currently, data is kept in information servers and cloud innovation as against the old method of putting away information in registers and records. Moreover, advancement of innovation and technology has similarly presented computerised showcasing stratagems through which organisations can offer their items and services. Indeed, even the innovative work by R\&D divisions in organisations has changed in its method for working and further developed systems in the improvement of items and services have been presented just through technological development. For instance, Siemens and Boeing are massively putting resources into the adaption of $3 \mathrm{D}$ printing strategy for item planning. They trust that this will quicken the planning procedure, diminish creation cost and enhance the viability of outlining (Abdulwahed 2017).

\section{Technology helps in developing marketing strategies}

Nowadays technology has undergone a significant revolution through which organisations gather, record, recover and use information and which can equally cause them to create pivotal business approaches and techniques. It is through accessible information, that the Kaohsiung City Government can screen and assess client patterns and their requests for a specific item or product and services. On account of the progression of data innovation and

\begin{tabular}{|c|c|c|c|}
\hline \multicolumn{2}{|c|}{$\begin{array}{l}\text { Talent } \\
\text { creative, non-linear } \\
\text { Comfort with ambiguity } \\
\text { Results-driven }\end{array}$} & \multicolumn{2}{|c|}{$\begin{array}{r}\text { Culture } \\
\text { Start-up-mindset } \\
\text { Agile, flexible and quick } \\
\text { Solutions orientation }\end{array}$} \\
\hline $\begin{array}{l}\text { Sense of urgency } \\
\text { Non-linear thinking }\end{array}$ & \multicolumn{2}{|c|}{$\begin{array}{c}\text { Leadership } \\
\text { Inspire and support behaviour change }\end{array}$} & $\begin{array}{r}\text { Can do attitude } \\
\text { Collaborative }\end{array}$ \\
\hline $\begin{array}{l}\text { Structure } \\
\text { For innovation }\end{array}$ & \multicolumn{2}{|c|}{$\begin{array}{c}\text { Act as role model } \\
\text { Tolerance for risk and failure - } \\
\text { innovation is different from } \\
\text { development } \\
\text { Provide safe and rewarding } \\
\text { environment }\end{array}$} & \\
\hline \multicolumn{2}{|c|}{$\begin{array}{l}\text { separate from development } \\
\text { Insulated, not isolated } \\
\text { Dedicated, small group to } \\
\text { lead and drive }\end{array}$} & Recognit & $\begin{array}{r}\text { Motivational } \\
\text { Training } \\
\text { ion and visibility } \\
\text { Metrics }\end{array}$ \\
\hline
\end{tabular}

Source: Makin, C., 2017, Adapting for the future: Promoting innovation in city government, viewed 10 August 2018, from https://www.wcmt.org.uk/sites/default/files/reportdocuments/ Makin\%20C\%20Report\%202017\%20Final.pdf.

FIGURE 4: Innovation culture (PricewaterhouseCoopers [PwC] digital services). 
technology, organisations can comprehend customers' behavioral conducts and lead a full-scale analysis and create the promoting methodologies if needs be (Leten et al. 2014). Technology is not helpful for gathering and utilising information; however, in this regard, it is likewise being utilised by institutions to examine information and make significant conclusions and additionally well-versed choices. Having more attention on the clients, business methodologies will positively end up being powerful for the achievement of a business entity and this is true with the Kaohsiung City Government.

\section{Conclusion}

This study shows that there are five key challenges faced by metropolitan cities or municipalities in managing competitive advantage through technology and innovation:

- $\quad R \& D$ and innovation - Manpower training and recruiting

- Information Security/Contingency Planning - Innovation and technology gives a great deal of benefits yet we ought to equally deliberate over the obligations that accompany it

- Rapidly advancing technologies - Technology is evolving quickly. Both those in client-facing services and those in supporting roles, must drive effectiveness and deliver on the obligation of providing value for money

- Ageing technology and underinvestment

- The change in residents' expectations

Challenges affecting the business or organisations, particularly City Governments as far as managing technology and innovation for competitive advantage are concerned are acknowledged based on the proven facts from the results of this research study. These include inter alias: challenges faced by S\&T development in KCG, Taiwan, such as R\&D and innovation, manpower training and recruiting, organisational transformation, information security or contingency planning, costs included in manging technology and innovation, lack of competence, rapidly advancing technologies, ageing technology and underinvestment, the change in residents' expectations, etc. As the consequence of this research, there is compelling evidence that proves the necessity of carrying out a comprehensive study of this magnitude, specifically focusing on city governments, in terms of managing sustainable advantage through technology and innovation. Furthermore, the five identified fundamental challenges facing metropolitan cities or municipalities in managing competitive advantage through technology and innovation can be a good lesson for the five major emerging economies: Brazil, Russia, India, China and South Africa (BRICS).

\section{Acknowledgements}

The authors thank Ms. Melissa Chen, Planning \& Promotion Division, Nationwide Document Delivery Service (NDDS), Science \& Technology Policy Research and Information Center (STPI), National Applied Research Laboratories (NARLabs), Taiwan, who granted permission to access data from Nationwide Document Delivery Service (NDDS) for this research study. The authors also wish to extend their gratitude to Ms. Genevieve Bakam Fotso for assisting in editing and proofreading.

\section{Competing interests}

The authors have declared that no competing interests exist.

\section{Authors' contributions}

K.T.T.A., the first author, was responsible for conducting the overall study, as well as formal analysis, methodology, writing and correspondence. E.I.E, A.K.G. and S.P. supervised, revised and edited the manuscript. All authors discussed the results and contributed to the final manuscript.

\section{Ethical considerations}

This article followed all ethical standards for research without direct contact with human or animal subjects.

\section{Funding information}

This research did not receive any specific grant from funding agencies in the public, commercial or not-for-profit sectors.

\section{Data availability}

Data sharing is not applicable to this article as no new data were created or analysed in this study.

\section{Disclaimer}

The views and opinions expressed in this article are those of the authors and do not necessarily reflect the official policy or position of any affiliated agency of the authors.

\section{References}

Abdulwahed, M., 2017, 'Technology Innovation and Engineering' Education and Entrepreneurship (TIEE) in engineering schools: Novel model for elevating national knowledge based economy and socio-economic sustainable development', Sustainability 9(2), 171. https://doi.org/10.3390/su9020171

Alavi, M. \& Leidner, D.E., 2001, 'Knowledge management and knowledge management systems: Conceptual foundations and research issues', MIS Quarterly 25(1), 107-136. https://doi.org/10.2307/3250961

Anderson, N., Potocnik, K. \& Zhou, J., 2014, 'Innovation and creativity in organizations: A state of the science review, prospective commentary, and guiding framework', Journa of Management 40(5), 1297-1333. https://doi.org/10.1177/0149206314527128

Attour, A. \& Chaupain-Guillot, S., 2020, 'Digital innovations in public administrations: Technological or policy innovation diffusion?', Journal of Innovation Economics \& Management 31(1), 195-219. https://doi.org/10.3917/jie.pr1.0061

Bleicher, K., 1991, Das Konzept integriertes management, Campus Verlag, Frankfurt.

Broström, A. \& Karlsson, S., 2017, 'Mapping research on R\&D, innovation and productivity: A study of an academic endeavour', Economics of Innovation and New Technology 26(1-2), 6-20. https://doi.org/10.1080/10438599.2016.1202519

Cavalcante, S.A., 2013, 'Understanding the impact of technology on firms' business models', European Journal of Innovation Management 16(3), 285-300. https:// doi.org/10.1108/EJIM-10-2011-0085

Cepeda-Carrión, G., Cegarra-Navarro, J.G. \& Leal-Millán, A., 2012, 'Finding the hospital-in-the-home units' innovativeness', Management Decision 50(9), 1596-1617. https://doi.org/10.1108/00251741211266705

Choy, M. \& Park, G., 2016, 'Sustaining innovative success: A case study on consumercentric innovation in the ICT industry', Sustainability 8(10), 986. https://doi. org/10.3390/su8100986

Cozzarin, B.P., Kim, W. \& Koo, B., 2017, 'Does organizational innovation moderate technical innovation directly or indirectly?', Economics of Innovation and New Technology 26(4), 385-403. https://doi.org/10.1080/10438599.201 6.1203084 
Crespi, F., 2004, 'Notes on the determinants of innovation: A multi-perspective analysis', The Fondazione Eni Enrico Mattei Note di Lavoro Series Index, viewed 15 February 2018, from http://www.feem.it/Feem/WPapers/default.htm.

Cummings, J.N., 2004, 'Work groups, structural diversity, and knowledge sharing in a global organization', Management Science 50(3), 352-364. https://doi.org/ $10.1287 / \mathrm{mnsc} .1030 .0134$

Denzin, N.K., \& Lincoln, Y.S., 2008, 'Introduction: The discipline and practice of qualitative research', in N.K. Denzin \& Y.S. Lincoln (eds.), Strategies of qualitative inquiry, pp. 1-43, Sage Publications, Thousand Oaks, CA.

De Vries, H., Bekkers, V. \& Tummers, L., 2016, 'Innovation in the public sector: A systematic review and future research agenda', Public Administration 94(1), 146-166. https://doi.org/10.1111/padm.12209

Dino, R.N., 2015, 'Crossing boundaries: Toward integrating creativity, innovation and entrepreneurship research through practice', Psychology of Aesthetics, Creativity and the Arts 9(2), 139-146. https://doi.org/10.1037/aca0000015

El-Kholei, A.O. \& Al Jayyousi, O.R., 2019, 'Technology-driven innovative municipalities: The case of Dubai Municipality', in A. Visvizi, S. Bakry, M.D. Lytras \& W. Alhalabi (eds.), Technology-driven innovation in Gulf Cooperation Council (GCC) countries: Emerging research and opportunities, pp. 24-48, IGI Global, Hershey, PA.

Freeman, C., 1995, 'The national system of innovation in historical perspective', Cambridge Journal of economics 19(1), 5-24.

Gibbons, M., 1994, The new production of knowledge: The dynamics of science and research in contemporary societies, Sage, London.

Goi, C.L., 2017, 'The impact of technological innovation on building a sustainable city' International Journal of Quality Innovation 3(1), 6. https://doi.org/10.1186/ s40887-017-0014-9

Goldsmith, S. \& Crawford, S., 2014, The responsive city: Engaging communities through data-smart governance, Jossey-Bass, San Francisco, CA.

Greenberg, S.R., 2015, Using innovation and technology to improve city services, IBM Center for the Business of Government, viewed 10 April 2021, from http://www. businessofgovernment.org/sites/default/files/Using $\% 2$ Innovation $\% 20$ and $\% 20$ Technology $\% 20$ to $\% 20$ Improve $\% 20$ City $\% 20$ Services.pdf.

Haned, N., Mothe, C. \& Nguyen-Thi, T.U., 2014, 'Firm persistence in technological innovation: The relevance of organizational innovation', Economics of Innovation and New Technology 23(5-6), 490-516. https://doi.org/10.1080/10438599.2014. 895509

Hashem, I.A.T., Chang, V., Anuar, N.B., Adewole, K., Yaqoob, I., Gani, A. et al., 2016, 'The role of big data in smart city', International Journal of Information Management 36(5), 748-758. https://doi.org/10.1016/j.ijinfomgt.2016.05.002

Huang, T., Wang, W.C., Ken, Y., Tseng, C.Y. \& Lee, C.L., 2010, 'Managing technology transfer in open innovation: The case study in Taiwan', Modern Applied Science 4(10), 2. https://doi.org/10.5539/mas.v4n10p2

Jiménez-Jiménez, D. \& Sanz-Valle, R., 2011, 'Innovation, organisational learning, and performance', Journal of Business Research 64(4), 408-417. https://doi. org/10.1016/j.jbusres.2010.09.010

Johnston, M.P., 2012, 'Connecting teacher librarians for technology integration leadership', School Libraries Worldwide 18(1), 18-23.

Kaohsiung City Government (KCG), 2014, Overview of Kaohsiung City Administration (2014), Research, Development and Evaluation Commission (RDEC), Kaohsiung
City Government, viewed 27 June 2018, from http://rdec.kcg.gov.tw/.

Kaohsiung City Government (KCG), 2015, Overview of Kaohsiung City Administration (2015), Research, Development and Evaluation Commission (RDEC), Kaohsiung City Government, viewed 24 July 2018, from http://rdec.kcg.gov.tw/.

Kaohsiung City Government (KCG), 2016, Overview of Kaohsiung City Administration (2016), Research, Development and Evaluation Commission (RDEC), Kaohsiung City Government, viewed 29 July 2018, from http://rdec.kcg.gov.tw/.

Kaohsiung City Government (KCG), 2017, Overview of Kaohsiung City Administration (2017), Research, Development and Evaluation Commission (RDEC), Kaohsiung City Government, viewed 20 July 2018, from http://rdec.kcg.gov.tw/.

Kim, K., 2017, 'Impact of firms' cooperative innovation strategy on technological convergence performance: The case of Korea's ICT industry', Sustainability 9(9) 1601. https://doi.org/10.3390/su9091601

Kuncoro, W. \& Suriani, W.O., 2017, 'Achieving sustainable competitive advantage through product innovation and market driving', Asia Pacific Management Review xxx $1-7$, viewed n.d., from https://iranarze.ir/wp-content/uploads/2018/01/ E5322-IranArze.pdf.

Leal-Rodríguez, A.L., Ariza-Montes, J.A., Roldán, J.L. \& Leal-Millán, A., 2014 'Absorptive capacity, innovation and cultural barriers: A conditional mediation
model', Journal of Business Research 67(5), 763-768. https://doi.org/10.1016/j. model', Journal of Busin

Lee, C., Hallak, R. \& Sardeshmukh, S.R., 2019, 'Creativity and innovation in the restaurant sector: Supply-side processes and barriers to implementation', Tourism Management Perspectives 31, 54-62. https://doi.org/10.1016/j.tmp.2019.03.011

Lin, C.Y. \& Ho, Y.H., 2007, 'Technological innovation for China's logistics industry', Journal of Technology Management \& Innovation 2(4), 1-19. https://doi. org/10.1108/17468770710723604

Makin, C., 2017, Adapting for the future: Promoting innovation in city government viewed 10 August 2018, from https://www.wcmt.org.uk/sites/default/files/ reportdocuments/Makin\%20C\%20Report \% 202017\%20Final.pdf.

Margaret, A.W. \& Garry, D.B., 2011, The management of technology and innovation: A strategic approach, Oklahoma State University, Stillwater, OK.

Martins, E.C. \& Terblanche, F., 2003, 'Building organisational culture that stimulates creativity and innovation', European Journal of Innovation Management 6(1), 64-74. https://doi.org/10.1108/14601060310456337
Matzler, K., Abfalter, D.E., Mooradian, T.A. \& Bailom, F., 2013, 'Corporate culture as an antecedent of successful exploration and exploitation' International Journal of Innovation Management 17(5), 1-23. https://doi.org/10.1142/ S1363919613500254

McAdam, R. \& Keogh, W., 2004, 'Transitioning towards creativity and innovation measurement in SMEs', Creativity and Innovation Management 13(2), 126-139. https://doi.org/10.1111/j.0963-1690.2004.00300.x

McCaston, M., 2005, Tips for collecting, reviewing, and analyzing secondary data, Partnership and household livelihood security unit, CARE, viewed 25 July 2018 , from http://pqdl.care.org/Practice/DME.

Ministry of Science and Technology (Taiwan) (MOST), 2018, Statistics Database, viewed 09 February 2018, from https://statistics.most.gov.tw/was2/.

Morck, R. \& Yeung, B., 2001, The economic determinants of innovation, Industry Canada Research Publications Program, Ottawa, ON, Occasional Paper Number 25 , January 2001

$\mathrm{Na}$, K., Kang, Y-H. \& Kim, Y.S., 2018, 'The effect of corporate governance on the corruption of firms in BRICs (Brazil, Russia, India \& China)', Social Sciences 7(6), 1-16. https://doi.org/10.3390/socsci7060085

National Development Council, 2015, Ide @ Taiwan 2020 (Creative Taiwan) Policy White Paper, National Development Council, Public Governance Quarterly, Taipei, Taiwan, vol. 3, pp. 93-100, National Development Council, Taipei City.

Porter, M., 1979, How competitive forces shape strategy, Harvard Business Review, Harvard Business School Publishing, Boston, MA.

Porter, M.E., 1996, 'What is strategy?', Harvard Business Review 74(6), 61-78.

Porter, M.E., 2008, 'The five competitive forces that shape strategy', Harvard Business Review 86(1), 25-40.

Porter, M.E. \& Millar, V.E., 1985, How information gives you competitive advantage, Harvard Business Review Reprint Service, New York: Free Press, New York, NY.

Przeybilovicz, E., Cunha, M.A. \& Tomor, Z., 2017, 'Identifying essential organizational characteristics for smart urban governance', Smart governance for sustainable cities: Proceedings of the 18th Annual International Conference, Staten Island, NY, June 07-09, 2017, https://doi.org/10.1145/3085228.3085281

Przeybilovicz, E., Da Silva, W.V. \& Cunha, M.A., 2015, 'Limits and potential for egov and smart city in local government: A cluster analysis concerning ICT infrastructure and use', International Journal of E-Planning Research (IJEPR) 4(2), 39-56. https:// doi.org/10.4018/ijepr.2015040103

Rampersad, G., Plewa, C. \& Troshani, I., 2012, 'Investigating the use of information technology in managing innovation: A case study from a university technology transfer office', Journal of Engineering and Technology Management 29(1), 3-21. https://doi.org/10.1016/j.jengtecman.2011.09.002

Schilling, M.A., 2010, Strategic management of technological innovation, Tata McGraw-Hill Education, New York, NY.

Schumpeter, J.A. \& Redvers, O., 1934, Theorie der wirtschaftlichen Entwicklung, The theory of economic development, An inquiry into profits, capital, credit, interest, and the business cycle, transl. R. Opie, Harvard University Press, Cambridge, MA.

Şener, S. \& Sarıdoğan, E., 2011, 'The effects of science-technology-innovation on competitiveness and economic growth', Procedia-Social and Behavioral Sciences 24, 815-828. https://doi.org/10.1016/j.sbspro.2011.09.127

Shearmur, R. \& Poirier, V., 2015, Exploring municipal innovation: Technological and original innovation in municipalities, viewed 12 April 2021, from http://www.ucs. inrs.ca/ucs/publications/collections/inedits.

Singh, J., 2008, 'Distributed R\&D, cross-regional knowledge integration and quality of innovative output', Research Policy 37(1), 77-96. https://doi.org/10.1016/j. respol.2007.09.004

Simonton, D.K., 2016, 'Defining creativity: Don't we also need to define what is not creative?', The Journal of Creative Behavior 52(1), 80-90. https://doi.org/10.1002/ jocb.137

Su, S., Chi, C., Su, M.Y. \& Chao, T.Y., 2017, Opportunities and challenges with digital economy trends, viewed 12 April 2021, from https://www.itri.org.tw/ Chi/Content/NewsLetter/contents.aspx?Sitel $D=1 \& M m m I D=5000 \& M S I D=74$ 4474650526526402

Suurs, R.A., 2009, Motors of sustainable innovation: Towards a theory on the dynamics of technological innovation systems, Utrecht University, Utrecht.

Svirina, A., Zabbarova, A. \& Oganisjana, K., 2016, 'Implementing open innovation concept in social business', Journal of Open Innovation: Technology, Market, and Complexity 2, 20. https://doi.org/10.1186/s40852-016-0046-8

Tschirky, H., 1998, Konzept und Aufgaben des Integrierten Technologie-Managements, Technologie-Management: Idee und Praxis, Zürich, pp. 193-394.

Tschirky, H., 2004, 'Wake-up call for general management: It's technology time', in Bringing technology and innovation into the boardroom, pp. 7-18, Palgrave Macmillan, London.

United Nations (UN), Department of Economic, 2016, United Nations e-governmet survey 2016: e-government in support of sustainable development, United Nations Publications, Nova York.

Uyarra, E., Edler, J., Garcia-Estevez, J., Georghiou, L. \& Yeow, J., 2014, 'Barriers to innovation through public procurement: A supplier perspective', Technovation 34(10), 631-645. https://doi.org/10.1016/j.technovation.2014.04.003

Visvizi, A., Lytras, M.D., Damiani, E. \& Mathkour, H., 2018, 'Policymaking for smart cities: Innovation and social inclusive economic growth for sustainability', Journal of Science and Technology Policy Management 9(2), 126-133. https://doi. org/10.1108/JSTPM-07-2018-079 
West, M.A. \& Farr, J.L. (eds.), 1990, Innovation and creativity at work: Psychological and organizational strategies, John Wiley \& Sons, Hoboken, NJ.

Wu, C. \& Lin, L., 2009, 'Guest editorial', Biotechnology Advances 27(5), 541. https:// doi.org/10.1016/j.biotechadv.2009.04.018

Wu, S.M., Chen, T.C., Wu, Y.J. \& Lytras, M., 2018, 'Smart cities in Taiwan: A perspective on big data applications', Sustainability 10(1), 106. https://doi.org/10.3390/su10010106

Yam, R.C.M., Guan, J.C., Pun, K.F. \& Tang, E.P.Y, 2004, 'An audit of technological innovation capabilities in Chinese firms: Some empirical findings in Beijing, China' Research Policy 33(8), 1123-1140. https://doi.org/10.1016/j.respol.2004.05.004
Yu, J. \& Lee, S., 2017, 'The impact of greenhouse gas emissions on corporate social responsibility in Korea', Sustainability 9(7), 1135. https://doi.org/10.3390/su9071135

Zahra, S., Abdelgawad, S.G. \& Tsang, E.W., 2011, 'Emerging multinational 220 venturing into developed economies: Implications for learning, unlearning, and entrepreneurial capability', Journal of Management Inquiry 20(3), 323-330. https://doi.org/10.1177/1056492611408266

Zhao, F., Collier, A. \& Deng, H., 2014, 'A multidimensional and integrative approach to study global digital divide and e-government development', Information Technology \& People 27(1), 38-62. https://doi.org/10.1108/ITP-012013-0022 